\title{
worldview
}

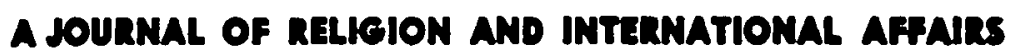

\section{THE EXCHANGE OF VISITS}

What would have seemed impossible (and almost unthinkable) a few years ago is coming to pass. During this month and next, the leaders of the world's two superpowers, whose vision and purposes remain implacably opposed, will inspect each other's countries with all the show of formal courtesy diplomacy demands.

The American people seem generally to have accepted this exchange of visits with a kind of resigned equanimity. If the public opinion polls are even remotely accurate, they continue to trust in Mr. Eisenhower's judgment to an almost alarming degree, and if the President thinks it wise to invite Mr. Khrushchev to Washington, then the public thinks it wise. A vocal minority of Americans, however, has raised serious questions about both the wisdom and the morality of the visits, and the minority's objections deserve comment.

These objections do not, as some liberals suppose, come only from the "extreme right." They come from there, to be sure, but they also come from men remarkable for their moderation and sound judgment-from distinguished religious leaders, political scientists, journalists and legislators. These men argue that by inviting Premier Khrushchev to our capitol we encourage the optimism about Soviet intentions that served us so ill at the summit conference of 1955, and betray the hopes of the captive peoples. In this new round of personal displomacy, they say, we again demonstrate our naivete about Soviet intentions ("Do we really think we can negotiate with the Communist leaders?") and lower our own moral standards.

One must honor the moral concern which these arguments express. And yet, one feels that in each case the concern is subtly misdirected. Mr. Eisenhower is not welcoming the Soviet dictator to the United States as a friend of freedom; he has invited him here as a necessary step in the strategy of world survival. The President's aim is not to placate our enemy; it is to convince him of our nation's determination and strength. For Americans to observe the ordinary civilities in carrying out this strategy is moral realism, not moral decay.

We were, of course, hopelessly optimistic in our 1955 journey to Geneva. At the start of that journey Mr. Eisenhower said some things that did demonstrate naivete about Soviet intentions. But we have learned much since 1955 and we are approaching the new conversations with only minimal expectations. We do not seriously expect that, because of them, the international situation will grow much better; we hope, rather, that through them it can be kept from growing worse. We are seeking for time to resolve the more dangerous crises of the Cold War.

In this seeking of time lies the best hopes for the captive peoples. We have long since stopped talking about "liberation" for the rather obvious reason that we can see no way to "liberate" the peoples behind the iron curtain without annihilating them and with them, probably, the vast majority of the human race. The only sound hope for liberation lies in a historical development of the Soviet system toward a greater flexibility. The development has begun during the past five years, and we must feel a moral obligation to encourage it.

We cannot have expectations of friendship with the Communist system as long as it remains, in any recognizable form, the present Communist system. But both the Communist leaders and the leaders of the "free" world are involved in a common fate, and this common fate makes some form of coexistence the only alternative to mutual suicide,

Faced with these alternatives, the standard objections to the Soviet dictator's visit seem tragically irrelevant. They are a reduction of our twentieth century situation, with all its terrors, to the rules of a parlor game. But the world we must save from self-destruction is not a polite society. It is a jungle in which the opposing camps must either talk together or die together. And so, though we cannot "welcome" Premier Khrush. chev, we are glad that he has come. 